\title{
Microbiological and physicochemical profiles of the sour cassava starch and bagasse obtained from cassava agroindustry
}

\author{
Marina Costa GARCIA ${ }^{1 *}$, Thaissa Machado ELIAS ${ }^{2}$, Keyla de Oliveira RIBEIRO ${ }^{1}$, Manoel Soares SOARES \\ JÚNIOR ${ }^{1}$, Márcio CALIARI $^{1}$
}

\begin{abstract}
The aim of this work was to evaluate the microbiological and physicochemical qualities of sour cassava starch and cassava bagasse produced during cassava agroindustry in order to evaluate their potential for use in food. All samples were kindly provided by family farmers producers from the region of Cará, in town of Bela Vista de Goiás, Brazil. All of sour cassava starch samples showed microbial counts within the values established by the current legislation. Drying process of raw cassava bagasse to produce the bran was sufficient to reduce the mold and yeast counts (from $1.9 \times 10^{3}$ to $3.5 \times 10^{1} \mathrm{CFU} \mathrm{g}^{-1}$ ) and of total coliform counts (from $2.1 \times 10^{3}$ to $2.4 \times 10^{2} \mathrm{MPN} 100 \mathrm{~mL}^{-1}$ ), and also eliminated the contamination by coliforms at $45^{\circ} \mathrm{C}$ and Bacillus cereus.

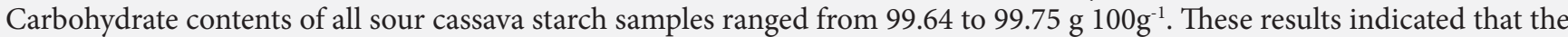
sour cassava starch presented high degree of purity, and extraction process was efficient. Bran sample showed high carbohydrate

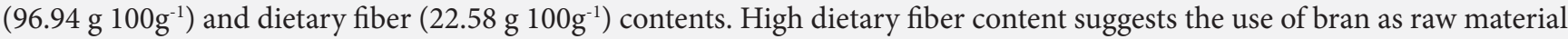
to increase the availability of fiber in food products, increasing its nutritional quality.
\end{abstract}

Keywords: agroindustry; Manihot esculenta; by-product; dietary fiber.

Practical Apllication: The wastes from cassava can be reused in industry applications reducing costs and adding value to food products.

\section{Introduction}

Cassava is one of the major crops in the world and the traditional product of economic importance produced in the agroindustry of cassava (Manihot esculenta) is cassava starch (Aquino et al., 2016; Edama et al., 2014). Cassava starch is classified as sweet and sour according to its acidity, with maximum values of 1.5 and $5.0 \%$, respectively (Brasil, 1978). Production of sour cassava starch starts with the extraction of the cassava starch, which consists of cleaning, peeling, chopping, pressing and straining of the cassava roots. The cassava starch is then submitted to natural fermentation, followed by sun drying for the production of sour cassava starch ("polvilho azedo") (Aquino et al., 2016; Demiate \& Kotovicz, 2011).

The fermentation of cassava starch to obtain the sour cassava starch is spontaneous process, developed by several microorganisms naturally present in the raw material, water and fermentation tanks. This characteristic explains the variation, found in the quality of the sour cassava starch to from several producers or from the same producer. The different Brazilian climatic conditions define the predominant microbiota in the fermentative processes, causing that sour cassava starch produced present differences related to the acidity and the composition of organic acids (Aquino et al., 2016). The sour cassava starch is considered a modified starch by oxidation due to action of organic acids (Garcia et al., 2016).
The global demand for native and modified starches is projected to grow from 35 million tons to 50 million between 2011 and 2015 (Felipe et al., 2013; Díaz et al., 2018), boosting production and increasing the amount of waste. The conservation of this residue is hampered by its high levels of humidity (85\%) (Abrahão et al., 2006). The drying of this byproduct would enable its proper conservation and transport, but raise the costs of acquisition (Fernandes et al., 2015). In 2015, Brazil produced 750 thousand tons of cassava starch (Associação Brasileira dos Produtores de Amido de Mandioca, 2018). In the starch factories, for each ton of roots processed, about $250 \mathrm{~kg}$ of cassava starch and $928.6 \mathrm{~kg}$ of cassava bagasse with $85 \%$ moisture are produced (Leonel \& Cereda, 2002). When one considers the production of starch, it can be estimated that 696 thousand tons of wet cassava bagasse were produced in Brazil in 2014. Thus, ongoing research is aiming to develop technologies for the use of cassava bagasse to obtain products with a high value, in which the cassava bagasse is used as an ingredient in fiber-rich food products (Fiorda et al., 2013b).

Cassava pulp contains about $50-70 \%$ mass as starch (on a dry mass basis) and $20-30 \%$ mass as fibers, which are composed mainly of cellulose and other non-starch polysaccharides (Rattanachomsri et al., 2009). Analysis of the chemical composition of cassava residue indicates the 
following: dry matter $86.5-94.5 \%$; organic matter $81.9-93.9 \%$; crude protein 4.1-6.5\%; hemicellulose and cellulose $34.4 \%$; and lignin 8.4\% (Kongkiattikajorn \& Sornvoraweat, 2011). Cassava bagasse is produced during extraction of the starch. Cassava residue is rich in fiber and residual starch (Leaes et al., 2013). Dry cassava bagasse present value of $61 \%$ of residual starch (dry basis) (Souto et al., 2017). This product may be intended for animal feed (Panichnumsin et al., 2010; Sriroth et al., 2000), for production of fermentable sugar by enzymatic hydrolysis (Souto et al., 2017), also be a source of biofuel (Sanchéz et al., 2017), but much of it is simply discarded as waste (Iyer et al., 2010; Panichnumsin et al., 2010). Even small manufacturing units, such as those from family farms can generate significant amounts of residue, since they usually agglomerate at a given location or city.

Although Brazil is one of the main producers of cassava and its byproducts, there is still no efficient use of residues by the cassava industry. Some researchers have shown the environmental problem arising from the residues generated from the agroindustrial activity of extracting starch from cassava (Camargo et al., 2008; Maieves et al., 2011; Panichnumsin et al., 2010). Proper use of this residue would help minimize environmental problems and could generate products with relevant industrial applications. Therefore, in order to use the cassava bagasse properly and add value to it, the physicochemical and microbiological properties should be determined by scientific and technological investigations. The characterization of these by-products is critical for their exploration and to check their potential for use in human food.

There are few studies with the application of these residues in human food probably due to lack of physicochemical and microbiological characterization. Fiorda et al. (2013b) evaluated the cooking properties of pasta made with cassava starch, cassava bagasse and amaranth flour. These authors reported that the elaboration of pasta shown to be a feasible alternative with respect to the technological and sensory aspects, and could be consumed by those suffering from gluten intolerance.

However, farinaceous products are highly susceptible to contamination by microorganisms. The contamination of farinaceous products by microorganisms such as bacteria and fungi can lead to changes in their chemical compositions, sensory properties and structures, a process known as deterioration, in addition to some of these microorganisms being pathogenic and causing diseases to humans (foodborne diseases). Several studies have highlighted the importance of studying the presence of fungi in grains and their by-products (Machado et al., 2009; Parada et al., 1996; Stefanello et al., 2012). Regarding the microbiological standards in Brazil, Resolution RDC ANVISA / MS n ${ }^{\circ}$ 12/2001 is currently in force, but it does not contemplate the determination of molds and yeasts.

The hygienic-sanitary condition is an accepted parameter for the determination of food microbiological quality. Microbiological analyses of food can be carried out to investigate the presence of microorganisms, quantify and identify the microorganisms, and to check on the hygienic-sanitary conditions of the process and thus ensure consumer health. Thus, since there are only a few studies published on the hygienic quality of sour cassava starch and the cassava bagasse produced during the extraction of cassava starch by family farmers, the aim of this work was to evaluate the microbiological and physicochemical quality of sour cassava starch provided by family farmers from the region of Cará, in town of Bela Vista de Goiás, Brazil. The cassava bagasse produced during the extraction of the cassava starch was also evaluated for the microbiological and physicochemical characteristics in order to evaluate its potential for use in food.

\section{Material and methods}

Commercial sour cassava starches, kindly provided by the Cooperativa Mista dos Pequenos Produtores de Polvilho e Derivados da Mandioca da Região do Cará (Cooperabs) from the town of Bela Vista de Goiás, Goiás, Brazil, were evaluated in this work. There are 33 family farmers who produce sour cassava starch and are associated with the cooperative Cooperabs. Due to the high number of sour cassava starch producers associated with Cooperabs, it was decided to use the statistical tool Sturges Frequency Distribution (Hoaglin et al., 1983) in order to minimize the number of other analyses necessary and represent them all by the total titratable acidity (TTA) ranges. Samples were previously designated to 6 classes and randomly selected according as described by Garcia et al. (2016). Using the Rule of Sturgers Frequency Distribution it was determined that the class amplitude of the TTA was 0.70 and 6 classes were defined. The TTA value of the first class varied from 2.16 to $2.86 \%$ and sample 1 was chosen for the evaluation, the second class varied from 2.87 to $3.57 \%$ (sample 2), the third class from 3.58 to $4.27 \%$ (sample 3), the fourth class from 4.28 to $4.98 \%$ (sample4), the fifth class from 4.99 to $5.69 \%$ (sample 5) and the sixth class from 5.70 to $6.40 \%$ (sample 6) (Garcia et al., 2016). Microbiological and physicochemical analyses were applied to the 6 samples.

The raw cassava bagasse was collected directly from the production line at each of the Cooperabs producers unit. The residues were packed in sterile polypropylene bags and then homogenized and submitted to artificial drying. Drying of the raw cassava bagasse to obtain the bran was carried out on trays in a convective dryer with an air temperature of $60^{\circ} \mathrm{C}$ for 12 hours. The dried product (bran) was ground in in an cyclone rotor mill. The ground bran was packed in polyethylene bags and stored in a horizontal freezer $\left(-18^{\circ} \mathrm{C}\right)$ until completion of the analyses.

\subsection{Microbiological analyses}

Microbiological analyses of the sour cassava starch, raw cassava bagasse and bran were carried out according to the methods recommended by the Brazilian Ministry of Agriculture, Liestock and Food Supply (MAPA), based on the techniques described in the American Public Health Association (Downes \& Ito, 2001). The samples were collected following the guidelines set out in ANVISA Resolution RDC No. 12 of January 2 $2^{\text {nd }}, 2001$ (Brasil, 2001), and dilutions prepared from $10^{-1}$ to $10^{-6}$. The inoculations were made according to the methodology proposed by Vanderzant \& Splittstoesser (1992) for the total aerobic mesophilic bacterial count, the mold and yeast count, the determination of the most probable number per gram of total and fecal coliforms, the Staphylococcus aureus count, determinations of Bacillus cereus, sulfite reducing Clostridia and Salmonella. The microbiological 
analyses were carried out in the Aqualit Technology Sanitation Laboratory, Goiânia, Goiás, Brazil.

\subsection{Physicochemical analyses}

The moisture content was determined by weight loss by heating at $105^{\circ} \mathrm{C}$ to constant weight, the ash content by complete incineration in a muffle furnace at $550{ }^{\circ} \mathrm{C}$, the total nitrogen by the Kjeldahl method, multiplying by 6.25 to estimate the crude protein content, the lipids by extracting with petroleum ether in a Soxhlet extractor; and the total dietary fiber by the enzymatic-gravimetric method. The above analyses were carried out according to the methods 925.10; 923.03; 31.1.08; 920. 39C; and 985.29, respectively, of the Association of Official Analytical Chemists (2010). The total carbohydrate content was estimated by difference (Brasil, 2003). The $\mathrm{pH}$ values were determined according to the method of the Instituto Adolfo Lutz (2005).

\subsection{Statistical analyses}

The chemical contents data was evaluated using the variance analysis (ANOVA) and the average compared by Tukey's test $(p<0.05)$ using Statística version 7.0 Software.

\section{Results and discussion}

\subsection{Microbiological analyses}

The Brazilian National Agency of Sanitary Surveillance (ANVISA) established the microbiological standards for food by way of RDC degree $n^{\circ} 12$ of January $2^{\text {nd }}, 2001$. Sour cassava starch and bran are included in item 10 of the legislation of Brazilian National Agency of Sanitary Surveillance (ANVISA). Bran is the food group includes products derived from grains and leguminous processing, mainly containing of bark and / or germ and also may contain parts of the endosperm of grains and leguminous. According to Brazilian health legislation published as RDC 12 (Brasil, 2001), which approves the technical regulation on microbiological standards for food, item 10 establishes the limits for flour, pasta, bakery products and similar as like as bran. For group of brans it is required a set up limit for Bacillus cereus of $3 \times 10^{3} \mathrm{CFU} \mathrm{g}^{-1}$, coliforms at $45^{\circ} \mathrm{C}$ of $10^{2} \mathrm{MPN}^{-1}$ and absence of Salmonella sp. However, the analyses carried out were the standard plate count of mesophilic aerobic bacteria, the mold and yeast count, total coliforms, Staphylococcus aureus and sulfite reducing Clostridium in order to verify the general quality conditions during the production of sour cassava starch and cassava bagasse.

All samples of sour cassava starch showed values of microorganisms within the limits established by the standards of the current legislation (Brasil, 2001) (Table 1). Sour cassava starch sample showed aerobic mesophilic bacterial counts between $1.0 \times 10^{1} \mathrm{CFU} \mathrm{g}^{-1}$ and $6.5 \times 10^{3} \mathrm{CFU} \mathrm{g}^{-1}$. High mesophilic bacterial counts may indicate a lack of hygienic-sanitary conditions during fermentation, but according to Carvalho et al. (1996), they may also represent the total microbial flora, since the culture medium used (PCA) allows for the growth of several microorganisms. Fermentation of cassava starch to produce sour cassava starch is traditionally carried out using the natural microbial flora present in the cassava starch. This flora microbial consists mainly of lactic, homo and heterofermentative bacteria with predominance of Lactobacillus plantarum (Figueroa et al., 1995; Carvalho et al.,1996; Parada et al., 1996; Silveira et al., 2003). The growth of lactic acid bacteria, yeasts and Bacillus sp was observed on the PCA medium by Amoa-Awua \& Jakobsen (1995) and Carvalho et al. (1996).

Samples of sour cassava starch showed low yeast and mold counts (Table 1) indicating a satisfactory sanitary hygienic process during their production. This result confirmed the growth of lactic bacteria and yeasts in the PCA medium in the total aerobic mesophilic bacterial count. The parameters for the aerobic mesophilic bacteria, molds and yeasts are not defined by the legislation, but Leitão (1988) considered count of these

Table 1. Microbiological analyses of the commercial starch samples, raw cassava bagasse and bran.

\begin{tabular}{|c|c|c|c|c|c|c|c|c|}
\hline \multirow[b]{2}{*}{ Samples } & \multicolumn{8}{|c|}{ Microorganisms } \\
\hline & $\begin{array}{c}\text { Aerobic } \\
\text { mesophilic } \\
\text { bacteria } \\
\left(\mathrm{CFU} \mathrm{g}^{-1}\right)\end{array}$ & $\begin{array}{l}\text { Molds and } \\
\text { yeasts } \\
\left(\mathrm{CFU} \mathrm{g}^{-1}\right)\end{array}$ & $\begin{array}{l}\text { Total Coliforms } \\
\left(\text { MPN } 100 \mathrm{~mL}^{-1}\right)\end{array}$ & $\begin{array}{l}\text { Coliform } 45^{\circ} \mathrm{C} \\
\left(\mathrm{MPN} 100 \mathrm{~mL}^{-1}\right)\end{array}$ & $\begin{array}{c}\text { Staphylococcus } \\
\text { aureus } \\
\left(\mathrm{CFU} \mathrm{g}^{-1}\right)\end{array}$ & $\begin{array}{l}\text { Bacillus cereus } \\
\quad\left(\mathrm{CFU} \mathrm{g}{ }^{-1}\right)\end{array}$ & $\begin{array}{l}\text { Sulfite reducing } \\
\text { Clostrídia } \\
\left(\mathrm{MPN} 100 \mathrm{~mL}^{-1}\right)\end{array}$ & $\begin{array}{l}\text { Salmonella sp. } \\
\left(\mathrm{CFU} 25 \mathrm{~g}^{-1}\right)\end{array}$ \\
\hline Sample 1 & $>6.5 \times 10^{3}$ & $6.0 \times 10^{1}$ & Absent & Absent & Absent & Absent & Absent & Absent \\
\hline Sample 2 & $6.0 \times 10^{1}$ & $2.5 \times 10^{2}$ & Absent & Absent & Absent & Absent & Absent & Absent \\
\hline Sample 3 & $<1.0 \times 10^{1}$ & $1.1 \times 10^{2}$ & Absent & Absent & Absent & Absent & Absent & Absent \\
\hline Sample 5 & $2.8 \times 10^{3}$ & $4.9 \times 10^{2}$ & Absent & Absent & Absent & Absent & Absent & Absent \\
\hline Sample 6 & $>6.5 \times 10^{3}$ & $4.0 \times 10^{1}$ & Absent & Absent & Absent & Absent & Absent & Absent \\
\hline $\begin{array}{l}\text { Raw } \\
\text { cassava } \\
\text { bagasse }\end{array}$ & $>6.5 \times 10^{3}$ & $1.9 \times 10^{3}$ & $2.1 \times 10^{3}$ & $6.8 \times 10^{1}$ & Absent & $1.0 \times 10^{1}$ & Absent & Absent \\
\hline Bran & $>6.5 \times 10^{3}$ & $3.5 \times 10^{1}$ & $2.4 \times 10^{2}$ & Absent & Absent & Absent & Absent & Absent \\
\hline
\end{tabular}


microorganisms between $10^{4}$ and $10^{6} \mathrm{CFU} \mathrm{g}^{-1}$ to be satisfactory for food. This fact was also reported by Dosea et al. (2010).

All the sour cassava starch samples showed the absence of Bacillus cereus, coliforms at $45^{\circ} \mathrm{C}$ and Salmonella sp. These results were within the limits established by the regulation (Brasil, 2001). They also showed the absence of total coliforms, Staphylococcus aureus and sulfite reducing Clostridia (Table 1). Dosea et al. (2010) showed values of mesophilic aerobic bacteria, molds and yeasts, total coliforms, coliforms at $45^{\circ} \mathrm{C}$ and Bacillus cereus of $\left(>106 \mathrm{CFU} \mathrm{g}^{-1},>106 \mathrm{CFU} \mathrm{g}^{-1}, 2.3 \mathrm{MPN} 100 \mathrm{~mL}^{-1}\right.$ and 2.3 MPN $100 \mathrm{~mL}^{-1}$, respectively), values higher than those found in the present study. These results showed that the sour cassava starch obtained from family farms in the region of Cará in Bela Vista, Goiás, presented microbiological standards which conformed with the legislation (Brasil, 2001), without no risks for human consumption.

The raw cassava bagasse obtained from the extraction of cassava starch was analyzed microbiologically to evaluate the need for treatment to control the microbial population (Table 1), aiming at the possibility of using the cassava bagasse to obtain bran, which can be used in food. The raw cassava bagasse presented values for Bacillus cereus, Coliforms at $45{ }^{\circ} \mathrm{C}$ and Salmonella sp. lower than the limits established by Resolution RDC n. 12 (Brasil, 2001). Bacillus cereus is a bacterium commonly found in the soil and in natural reservoirs and, for this reason is frequently contaminant of plants, cereals and tubers, and is associated with contamination by emetic toxins (Ghelardi et al., 2002; Minnaard et al., 2001).

The artisanal way of obtaining sour cassava starch allows for considerable microbial contamination during the process. According to Chisté et al. (2007), the problems with the production of sour cassava starch are due to the precariousness of the family farm producers, the presence of domestic animals in the production unit, the lack of hygiene of the production staff and the non-sanitation of the machinery. In addition, it is important to consider that the contamination by microorganisms may come from the cassava peel, because the cassava bagasse contains small amount of the peel obtained during the starch extraction process. The variation of the microbiology and physicochemical quality of sour cassava starch is due to the non-standardized obtaining process in the rural industry (family farm producers) (Díaz et al., 2018).
The counts of aerobic mesophilic bacteria, molds and yeasts, and total coliforms in the raw cassava bagasse presented values of $>6.5 \times 10^{3} \mathrm{CFU} \mathrm{g}^{-1}, 1.9 \times 10^{3} \mathrm{CFU} \mathrm{g}^{-1}$, and $2.1 \times 10^{2} \mathrm{MPN} 100 \mathrm{~mL}^{-1}$, respectively. In addition, Staphylococcus aureus, sulfite reducing Clostridat and Salmonella sp. were absent. These results indicated a low level of microbiological contamination, as already reported by Leitão (1988) who stated that values of up to $10^{6} \mathrm{CFU} \mathrm{g^{-1 }}$ of aerobic mesophilic bacteria and of molds and yeasts were satisfactory in foods.

After drying the raw cassava bagasse $\left(65^{\circ} \mathrm{C}\right)$, the bran presented microbiological parameters within the established food standards (Brasil, 2001). The values obtained for total coliforms in the raw cassava bagasse $\left(2.1 \times 10^{3} \mathrm{MPN} 100 \mathrm{~mL}^{-1}\right)$ were higher than those obtained in the dry cassava cassava bagasse $\left(2.4 \times 10^{2} \mathrm{MPN} 100 \mathrm{~mL}^{-1}\right)$. The raw cassava bagasse was dry for to produce the dry cassava bagasse. Dry cassava bagasse is called bran. The process of drying the raw cassava bagasse to produce the bran, reduced the counts of total coliforms (from $2.1 \times 10^{3}$ to $2.4 \times 10^{2} \mathrm{MPN} 100 \mathrm{~mL}^{-1}$ ) and molds and yeasts (from $1.9 \times 10^{3}$ to $3.5 \times 10^{1} \mathrm{CFU} \mathrm{g}^{-1}$ ), and eliminated the contamination by coliforms at $45^{\circ} \mathrm{C}$ and by Bacillus cereus. These results showed that the drying process was sufficient to eliminate the microbial flora of the raw cassava bagasse, suggesting that the bran could be used in food without any further treatment.

\subsection{Physicochemical analyses}

The $\mathrm{pH}$ values of the sour cassava starch samples presented significant differences ( $\mathrm{p} \leq 0.05)$, sample 1 showed the highest value (4.01) and sample 6 the lowest value (3.38) (Table 2). This reduction in $\mathrm{pH}$ is related to the lower and higher values of titratable acidity values of samples 1 and 6 , of 2.55 and 6.26, respectively (Garcia et al., 2016), due to the production of organic acids during the natural fermentation of the sour cassava starch. Ladeira \& Pena (2011) and Marcon et al. (2009) also reported low $\mathrm{pH}$ values for sour cassava starch (from 3.24 to 3.53 and from 3.73 to 4.36 , respectively). Aquino et al. (2016) also reported for sour cassava starches $\mathrm{pH}$ values from 3.11 to 4.82 . These values were similar to those found in this study.

The sour cassava starch samples presented moisture contents within the range from $10-15 \%$ (Table 2), considered to be optimal for native starches, modified starches and flours, avoiding very dry products with probable structural degradation and those

Table 2. Chemical constituents and $\mathrm{pH}$ of commercial sour cassava starch and the bran.

\begin{tabular}{|c|c|c|c|c|c|c|c|}
\hline Constituent $^{1}\left[\mathrm{~g}(100 \mathrm{~g})^{-1}\right]^{1}$ & Sample 1 & Sample 2 & Sample 3 & Sample 4 & Sample 5 & Sample 6 & Bran \\
\hline Moisture $^{2}$ & $14.32 \pm 0.07^{\mathrm{a}}$ & $12.74 \pm 0.25^{\mathrm{b}}$ & $12.84 \pm 0.21^{\mathrm{b}}$ & $10.59 \pm 0.16^{\mathrm{e}}$ & $12.42 \pm 0.20^{c}$ & $11.02 \pm 0.11^{\mathrm{d}}$ & $6.16 \pm 0.20$ \\
\hline Ash & $0.09 \pm 0.01^{\mathrm{a}}$ & $0.07 \pm 0.01^{\mathrm{bc}}$ & $0.08 \pm 0.01^{\mathrm{abc}}$ & $0.08 \pm 0.02^{\mathrm{ab}}$ & $0.06 \pm 0.01^{c}$ & $0.09 \pm 0.00^{\mathrm{a}}$ & $1.31 \pm 0.04$ \\
\hline Protein & $0.08 \pm 0.00^{\mathrm{bc}}$ & $0.07 \pm 0.00^{c}$ & $0.09 \pm 0.01^{\mathrm{b}}$ & $0.09 \pm 0.01^{\mathrm{b}}$ & $0.08 \pm 0.00^{\mathrm{b}}$ & $0.11 \pm 0.00^{\mathrm{a}}$ & $1.28 \pm 0.00$ \\
\hline Lipids & $0.14 \pm 0.01^{\mathrm{b}}$ & $0.21 \pm 0.03^{\mathrm{a}}$ & $0.11 \pm 0.01^{\mathrm{c}}$ & $0.20 \pm 0.02^{\mathrm{a}}$ & $0.13 \pm 0.01^{\mathrm{bc}}$ & $0.14 \pm 0.04^{\mathrm{b}}$ & $0.47 \pm 0.01$ \\
\hline Total dietary fiber & $2.84 \pm 0.35^{\mathrm{a}}$ & $2.24 \pm 0.12^{\mathrm{c}}$ & $2.76 \pm 0.11^{\mathrm{ab}}$ & $2.49 \pm 0.10^{\mathrm{bc}}$ & $2.51 \pm 0.18^{\mathrm{bc}}$ & $2.20 \pm 0.07^{\mathrm{c}}$ & $22.58 \pm 0.05$ \\
\hline Carbohydrates $^{3}$ & 99.69 & 99.65 & 99.75 & 99.64 & 99.75 & 99.66 & 96.94 \\
\hline $\mathrm{pH}$ & $4.01 \pm 0.02^{\mathrm{a}}$ & $3.80 \pm 0.05^{\mathrm{b}}$ & $3.76 \pm 0.04^{\mathrm{b}}$ & $3.62 \pm 0.03^{c}$ & $3.56 \pm 0.02^{c}$ & $3.38 \pm 0.01^{\mathrm{d}}$ & $5.19 \pm 0.03$ \\
\hline
\end{tabular}

${ }^{1}$ Mean with different letters in the same row are statistically different by the Tukey's test $(\mathrm{p}<0.05) ;{ }^{2}$ Moisture on a wet weight basis and other components on a dry weight basis; ${ }^{3} \mathrm{Carbohydrates}$ were calculated by subtracting the moisture, ash, protein, lipids and total dietary fiber from one hundred; Sample 1 ( class 1: total titratable acidity - TTA from 2.16 to $2.86 \%$ ); Sample 2 (class 2: TTA from 2.87 to 3.57\%); Sample 3 (class 3: TTA from 3.58 to 4.27\%); Sample 4 (class 4: TTA from 4.28 to 4.98\%;) Sample 5 (class 5: TTA from 4.99 to $5.69 \%$ ) and Sample 6 (class 6: TTA from 5.70 to $6.40 \%$ ) (Garcia et al., 2016). 
with high water activity, which would favors the proliferation of microorganisms (Tester, 1997). The moisture ranges for commercial sour cassava starch found in this work were the same as those reported by Marcon et al. (2009), Ladeira \& Pena (2011), Pereira et al. (1999) and Aquino et al. (2016)

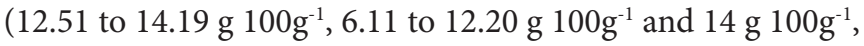

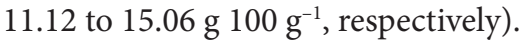

There were significant differences $(\mathrm{p} \leq 0.05)$ in $\mathrm{pH}$ between samples of sour cassava starch with different total titratable acidity values. However, the cassava cultivar used the same for all the sour cassava starch samples, which may have influenced the climatic conditions during drying in the sun. Aquino et al. (2016) characterized the sour cassava starch in factories of Santa Catarina State and reported $\mathrm{pH}$ values from 3.11 to 4.82 . The $\mathrm{pH}$ values (3.38 to 4.01) of sour cassava starch found in this work were the same as those reported Aquino et al. (2016).

Starch consists mainly of carbohydrates, however, substances such as lipids, proteins and ashes are present in its composition. The amounts of these substances in the of the sour cassava starch depend on the plant and the extraction method. The purity of the starch depends on the amount of minor constituents, such as lipids, proteins, phosphorus and ashes which vary with the botanical source and the extraction process used. According to Franco et al. (2002) it is important that the of the sour cassava starch presents low levels of minor constituents, and of these the lipid and phosphorus fractions are the most important, since they influence the physicochemical properties of the starches. Carbohydrate contents of all the samples were high, ranging

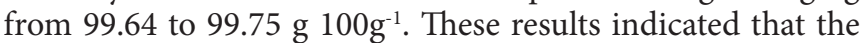
starches were very pure and that the cassava starch extraction process was efficient.

Lipid content of the sour cassava starch varied significantly

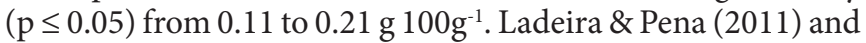
Pereira et al. (1999) reported similar values to those found in

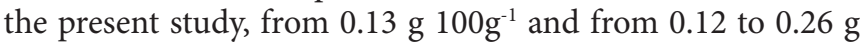
$100 \mathrm{~g}^{-1}$, respectively. Camargo et al. (2008) showed lipid value of $0.14{\mathrm{~g} 100 \mathrm{~g}^{-1}}$ for cassava starch. These values are in agreement with Moorthy (2002), who reported that root and tuber starches

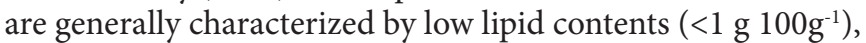
which has no pronounced effect on the physicochemical properties when compared to cereal starches (Hoover, 2001). Researches have been reported with lipid value varies between

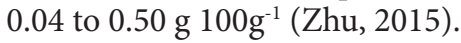

The ash and protein values of the sour cassava starch samples varied significantly $(\mathrm{p} \leq 0.05)$ from 0.06 to $0.09 \mathrm{~g} 100 \mathrm{~g}-1$, and from 0.07 to $0.11 \mathrm{~g} 100 \mathrm{~g}-1$, respectively (Table 2 ). Ash values found in this work were similar to those presented by Marcon et al.

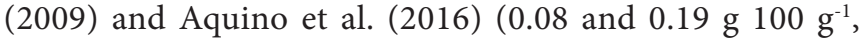

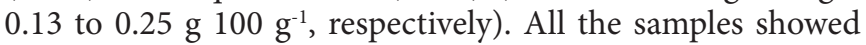
values lower than $0.5 \%$ for ash, which is the maximum limit established for sour cassava starch (Brasil, 1978). The low values found for proteins in the samples of sour cassava starch

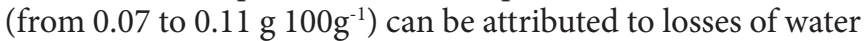
soluble proteins during the washing of the starches, this fact also was shown by Ladeira \& Pena (2011). Proteins contents found in the sour cassava starch samples by Pereira et al.

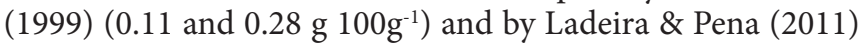

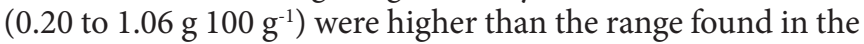

present study. Sample 6, representing the sour cassava starch sample with the highest titratable acidity range (Garcia et al.,

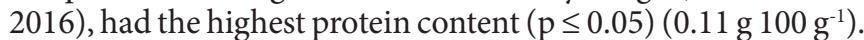
This was justified by the fact that sour cassava starch with higher acidity presents a higher production of proteinaceous substances, such as enzymes, by the microorganisms, during the fermentation process (Pereira et al., 1999; Plata-Oviedo \& Camargo, 1998). The organic acids produced during the fermentation process in the sour cassava starch degraded the starch granule (Garcia et al., 2016), which could also affect the composition of the minor constituents of the starch, such as protein.

The dry cassava bagasse (called bran) produced as a result of extraction of starch from the cassava had a moisture content of $6.16 \%$ (Table 2), a value below the maximum moisture content established by the legislation for bran, which is $15 \mathrm{~g} 100 \mathrm{~g}-1$ (Brasil, 2005). In addition to conforming to the maximum moisture limit, the low moisture condition of the bran was also triggered to facilitated the grinding process and the prevention of microbial growth during storage.

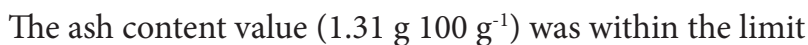
established by the legislation (maximum of 2.0\%) (Brasil, 2005). High ash values may indicate fraud or improper processing (Fiorda et al., 2013a).

Lipid and protein contents found in this study were $0.47{\mathrm{~g} 100 \mathrm{~g}^{-1}}^{-1}$

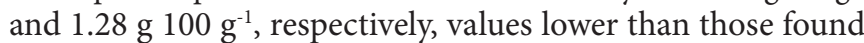
by Camargo et al. (2008) (5.3 g 100-1 for lipid and $0.92{\mathrm{~g} 100 \mathrm{~g}^{-1}}^{-1}$ for protein) and by Fiorda et al. (2013a) $\left(2.35 \mathrm{~g} 100^{-1}\right.$ for lipid

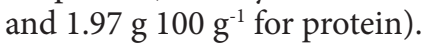

The bran had a high carbohydrate content (96.94), which may consist mainly of starch. Previous research of the dry cassava bagasse reported starch value of $60.68 \mathrm{~g} 100 \mathrm{~g}^{-1}$ (Souto et al., 2017). Camargo et al. (2008) reported that much of the carbohydrates

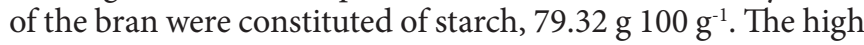
starch content means low efficiency of the extraction process.

The main components of bran are dietary fiber and starch. The value found for total dietary fiber in the present study $\left(22.58 \mathrm{~g} 100 \mathrm{~g} \mathrm{~g}^{-1}\right)$ was higher than that reported by Camargo et al. (2008)

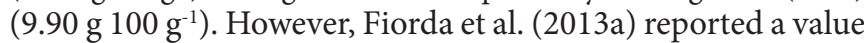

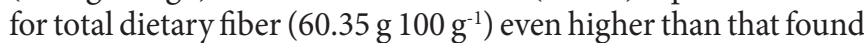

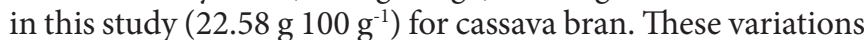
may be due to variations in the cassava starch extraction process, ranging from small manufacturing units on family farms to medium-sized industries.

The high dietary fiber content reinforces the use of bran as raw material to increase the availability of fiber in food products, increasing their nutritional quality. The results indicate the use of bran to substitute the flours traditionally used as fiber sources in food products such as cakes, cookies, biscuits and pasta, and may allow on to claim functionality properties for the products. There are some published works with the applications of bran as fiber source in foods such as pasta and biscuits (Fiorda et al., 2013b; Camargo et al., 2008).

\section{Conclusions}

The sour cassava starch samples presented microbial counts within the values established by current Brazilian legislation, with no risks of for human consumption. Raw cassava bagasse 
also presented microbiological parameters below the limits established by the legislation, and the drying process was sufficient to eliminate the microbial flora of the raw cassava bagasse, suggesting that the bran could be used in foods with no further treatment.

Sour cassava starch samples were characterized by low ash, protein and lipid contents. As expected, the variation between the samples in relation to the titratable acidity affected the $\mathrm{pH}$ variation, but did not drastically interfere in their chemical compositions (lipid content, total fiber, protein and ash).

Bran is obtained from the raw cassava bagasse which is the by-product of the production of cassava starch and sour cassava starch. The bran is characterized by the high total dietary fiber content, and can be considered as an alternative ingredient for the food industry. The use of this bran in food products may allow one to claim functional properties for these products.

\section{Acknowledgements}

The authors thanks the Cooperativa Mista dos Pequenos Produtores de Polvilho e Derivados da Mandioca da Região do Cará de Bela Vista de Goiás (Cooperabs) in the town of Bela Vista de Goiás, Brazil, for providing the samples of sour cassava starch, and to the Aqualit Tecnologia em Saneamento Ltda, Goiânia, Goiás, Brazil for carrying out the microbiological analyses.

\section{References}

Abrahão, J. J. S., Prado, I. N., Marques, J. A., Perotto, D., \& Lugao, S. M. B. (2006). Effects of replacing corn with dry cassava by-product on production of feedlot crossbred heifers. Revista Brasileira de Zootecnia, 35, 512-518.

Amoa-Awua, W. K. A., \& Jakobsen, M. (1995). The role of Bacillus species in the fermentation of cassava. The Journal of Applied Bacteriology, 79(3), 250-256. http://dx.doi.org/10.1111/j.1365-2672.1995.tb03134.x.

Aquino, A. C. M. S., Gervin, V. M., \& Amante, E. R. (2016). Evaluation of the sour cassava starch productive processing on factories of Santa Catarina State. Brazilian Journal of Food Technology, 19, 1-8.

Associação Brasileira dos Produtores de Amido de Mandioca - ABAM. (2018). Paranavaí: ABAM. Retrieved from http://www.abam.com. br/estatisticas-producao.php

Association of Official Analytical Chemists - AOAC. (2010). Official methods of analysis of AOAC International: agricultural chemicals, contaminants, drugs (18th ed.). Gaithersburg: AOAC International.

Brasil, Ministério da Saúde. (1978, Jul 24). Resolução CNNPA n. 12, 24 de julho de 1978. Normas técnicas especiais relativas a alimentos e bebidas. Diário Oficial [da] República Federativa do Brasil, Brasília, DF, Seção I, pt I.

Brasil, Ministério da Saúde. (2001, Jan 02). Resolução RDC n. 12, 02 de janeiro de 2001. Regulamento Técnico sobre Padrões Microbiológicos para Alimentos. Diário Oficial [da] Republica Federativa do Brasil, Brasília, DF.

Brasil, Ministério da Saúde. (2003, 23 Dez). Resolução RDC n. 360, de 23 de dezembro de 2003. Regulamento Técnico sobre Rotulagem Nutricional de Alimentos Embalados, tornando obrigatória a rotulagem nutricional. Diário Oficial [da] República Federativa do Brasil, Brasília, DF.

Brasil, Ministério da Saúde. (2005, 22 Set). Resolução RDC n. 263, 22 de setembro de 2005. Regulamento técnico para produtos de cereais, amidos, farinhas e farelos. Diário Oficial [da] Republica Federativa do Brasil, Brasília, DF.

Camargo, K. F., Leonel, M., \& Mischan, M. M. (2008). Production of snacks from sour cassava starch and fiber: effect of operational parameters on physical properties. Food Science and Technology, 28(3), 586-591. http://dx.doi.org/10.1590/S0101-20612008000300013.

Carvalho, E. P., Canhos, V. P., Ribeiro, V. E., \& Carvalho, H. P. (1996). Polvilho azedo: physical-chemical and microbiological aspects. Pesquisa Agropecuária Brasileira, 31, 129-137.

Chisté, R. C., Cohen, K. O., Mathias, E. A., \& Ramoa, A. G. A. Jr. (2007). Study of physical-chemical and microbiological properties when processing cassava flour from the water group. Food Science and Technology, 27, 265-269.

Demiate, I. M., \& Kotovicz, V. (2011). Cassava in the Brazilian food industry. Food Science and Technology, 31(2), 388-397. http://dx.doi. org/10.1590/S0101-20612011000200017.

Díaz, A., Dini, C., Viña, S. Z., \& García, M. A. (2018). Technological properties of sour cassava starches: Effect of fermentation and drying processes. Lebensmittel-Wissenschaft + Technologie, 93, 116-123. http://dx.doi.org/10.1016/j.lwt.2018.03.029.

Dosea, R. R., Marcellini, O. S., Santos, A. A., Ramos, A. L. D., \& Lima, A. S. (2010). Microbiological quality in the flour and starch cassava processing in traditional and model unit. Ciência Rural, 40, 441-445.

Downes, F. P., \& Ito, K. (2001). Compendium of methods for the microbiological examination for foods. Washington: American Public Health Association. http://dx.doi.org/10.2105/9780875531755.

Edama, N. A., Sulaiman, A., \& Rahim, S. N. A. (2014). Enzymatic saccharification of Tapioca processing wastes into biosugars through immobilization technology (Mini Review). Biofuel Research Journal, 1(1), 2-6. http://dx.doi.org/10.18331/BRJ2015.1.1.3.

Felipe, F. I., Alves, L. R. A., \& Vieira, R. M. (2013, Março). Fécula de mandioca: produção na Tailândia versus Brasil. Mercado \& Negócios, Agroanalysis. Retrieved from http://www.agroanalysis. com.br/3/2013/mercado-negocios/fecula-de-mandioca-producaona-tailandia-versus-brasil

Fernandes, T., Zambom, M. A., Castagnara, D. D., Souza, L. C., Damasceno, D. O., \& Schmidt, E. L. (2015). Use of dried waste of cassava starch extraction for feedin lactating cows. Anais da Academia Brasileira de Ciencias, 87(2), 1101-1111. http://dx.doi. org/10.1590/0001-3765201520140220. PMid:25860971.

Figueroa, C., Davila, A. M., \& Pourquié, J. (1995). Lactic acid bactéria of the sour cassava starch fermentation. Letters in Applied Microbiology, 21(2), 126-130. http://dx.doi.org/10.1111/j.1472-765X.1995.tb01023.x.

Fiorda, F. A., Soares, M. S. Jr., Silva, F. A., Souto, L. R. F., \& Grossmann, M. V. E. (2013a). Cassava bagasse flour: byproduct utilization and comparison with cassava starch. Pesquisa Agropecuária Tropical, 43(4), 408-416. http://dx.doi.org/10.1590/S1983-40632013000400005.

Fiorda, F. A., Soares, M. S. Jr., Silva, F. A., Souto, L. R. F., Silva, F. A., \& Grossmann, M. V. E. (2013b). Amaranth flour, cassava starch and cassava bagasse in the production of gluten-free pasta: technological and sensory aspects. International Journal of Food Science \& Technology, 48(9), 1977-1984. http://dx.doi.org/10.1111/ijfs.12179.

Franco, C. M. L., Wong, K. S., Yoo, S., \& Jane, J. (2002). Structural and functional characteristics of selected soft wheat starches. Cereal Chemistry, 79(2), 243-248. http://dx.doi.org/10.1094/ CCHEM.2002.79.2.243.

Garcia, M. C., Franco, C. M. L., Soares, M. S. Jr., \& Caliari, M. (2016). Structural característics and gelatinization properties of sour cassava starch. Journal of Thermal Analysis and Calorimetry, 123(2), 919-926. http://dx.doi.org/10.1007/s10973-015-4990-5. 
Ghelardi, E., Celandroni, F., Salvetti, S., Barsotti, C., Baggiani, A., \& Senesi, S. (2002). Identification and characterization of toxigenic Bacillus cereus isolates responsible for two food-poisoning outbreaks. FEMS Microbiology Letters, 208(1), 129-134. http:// dx.doi.org/10.1111/j.1574-6968.2002.tb11072.x. PMid:11934506.

Hoaglin, D. C., Mosteller, F., \& Tukey, J. W. (1983). Understanding robust and exploratory data analysis. New York: Wiley.

Hoover, R. (2001). Composition, molecular structure, and physicochemical properties of tuber and root starches: a review. Carbohydrate Polymers, 45(3), 253-267. http://dx.doi.org/10.1016/S0144-8617(00)00260-5.

Instituto Adolfo Lutz. (2005). Normas analíticas do Instituto Adolfo Lutz: métodos químicos e físicos para análises de alimentos (4. ed.). São Paulo: Instituto Adolfo Lutz.

Iyer, S., Mattinson, D., \& Fellman, J. (2010). Study of the early events leading to cassava root postharvest deterioration. Tropical Plant Biology, 3(3), 151-165. http://dx.doi.org/10.1007/s12042-010-9052-3.

Kongkiattikajorn, J., \& Sornvoraweat, B. (2011). Comparative study of bioethanol production from cassava peels by monoculture and co-culture of yeast. Witthayasan Kasetsat Witthayasat, 274, 268-274.

Ladeira, T. M. S., \& Pena, R. S. (2011). Propriedades físico-químicas e tecnológicas dos polvilhos azedos de três cultivares de mandioca. Alimentos e Nutrição, 22, 631-640.

Leaes, E. X., Zimmermann, E., Souza, M., Ramon, A. P., Mezadri, E. T., Dal Prá, V. D., Terra, L. M., \& Mazutti, M. A. (2013). Ultrasoundassisted enzymatic hydrolysis of cassava waste to obtain fermentable sugars. Biosystems Engineering, 115(1), 1-6. http://dx.doi.org/10.1016/j. biosystemseng.2013.02.001.

Leitão, M. F. F. (1988). Tratado de microbiologia. In I. Roitman, L. R. Travasso, \& J. L. Azevedo (Eds.), Microorganismos patogênicos em alimentos. São Paulo: Manole.

Leonel, M., \& Cereda, M. P. (2002). Physicochemical characterization of some starchy tubers. Food Science and Technology, 22(1), 65-69. http://dx.doi.org/10.1590/S0101-20612002000100012.

Machado, A. C. R., Monteiro, A. C., Mochi, D. A., \& Yoshida, L. (2009). Resíduos e subprodutos agroindustriais e grãos como subprodutos para produção do fungo entomopatogênico Lecanicillium lecanil. Revista Bragantia, 68(3), 703-714. http://dx.doi.org/10.1590/S000687052009000300018.

Maieves, H. A., Oliveira, D. C., Frescura, J. R., \& Amante, E. R. (2011). Selection of cultivars for minimization of waste and of water consumption in cassava starch production. Industrial Crops and Products, 33(1), 224-228. http://dx.doi.org/10.1016/j.indcrop.2010.10.017.

Marcon, M. J. A., Kurtz, D. J., Raguzzoni, J. C., Delgadillo, I., Maraschin, M., Soldi, V., Reginatto, V., \& Amante, E. R. (2009). Expansion properties of sour cassava starch (polvilho azedo): variables related to its practical application in bakery. Stärke, 61(12), 716-726. http:// dx.doi.org/10.1002/star.200900132.

Minnaard, J., Humen, M., \& Pérez, P. F. (2001). Effect of Bacillus cereus Exocellular Factors on Human Intestinal Epithelial Cells. Journal of Food Protection, 64(10), 1535-1541. http://dx.doi.org/10.4315/0362028X-64.10.1535. PMid:11601702.

Moorthy, S. N. (2002). Physicochemical and functional properties of tropical tuber starches: a review. Stärke, 54(12), 559-592.
http://dx.doi.org/10.1002/1521-379X(200212)54:12<559::AIDSTAR2222559>3.0.CO;2-F.

Panichnumsin, P., Nopharatana, A., Ahring, B., \& Chaiprasert, P. (2010). Production of methane by co-digestion of cassava pulp with various concentrations of pig manure. Biomass and Bioenergy, 34(8), 11171124. http://dx.doi.org/10.1016/j.biombioe.2010.02.018.

Parada, J. L., Zapata, E., Fabrizio, S. V., \& Martínez, A. (1996). Microbiological and technological aspects of cassava-starch fermentation. World Journal of Microbiology \& Biotechnology, 12(1), 53-56. http://dx.doi. org/10.1007/BF00327801. PMid:24415089.

Pereira, J., Ciacco, C. F., Vilela, E. R., \& Teixeira, A. L. S. (1999). Fermented starch in the biscuit manufacturing: alternative sources. Food Science and Technology, 19, 287-293.

Plata-Oviedo, M., \& Camargo, C. (1998). Effect of acid treatments and drying processes on physicochemical and functional properties of cassava starch. Journal of the Science of Food and Agriculture, 77(1), 103-108. http://dx.doi.org/10.1002/(SICI)1097-0010(199805)77:1<103::AIDJSFA10>3.0.CO;2-2.

Rattanachomsri, U., Tanapongpipat, S., Eurwilaichitr, L., \& Champreda, V. (2009). Simultaneous non-thermal saccharification of cassava pulp by multi-enzyme activity and ethanol fermentation by Candida tropicalis. Journal of Bioscience and Bioengineering, 107(5), 488-493. http://dx.doi.org/10.1016/j.jbiosc.2008.12.024. PMid:19393545.

Sanchéz, A. S., Silva, Y. L., Kalid, R. A., Cohim, E., \& Torres, E. A. (2017). Waste bio-refineries for the cassava starch industry: New trends and review of alternatives. Renewable \& Sustainable Energy Reviews, 73, 1265-1275. http://dx.doi.org/10.1016/j.rser.2017.02.007.

Silveira, I. A., Carvalho, E. P., Padua, I. P. M., \& Dionizio, F. L. (2003). Isolamento e caracterização da microbiota ácido lática envolvida no processo fermentativo para produção de polvilho azedo. Pró Homine, 2, 7-14.

Souto, L. R. F., Caliari, M., Soares, M. S. Jr., Fiorda, F. A., \& Garcia, M. C. (2017). Utilization of residue from cassava starch processing for production of fermentable sugar by enzymatic hydrolysis. Food Science and Technology, 37(1), 19-24. http://dx.doi.org/10.1590/1678457x.0023.

Sriroth, K., Piyachomkwan, K., Wanlapatit, S., \& Oates, C. G. (2000). Cassava starch technology: the Thai experience. Stärke, 52(12), 439449. http://dx.doi.org/10.1002/1521-379X(200012)52:12<439::AIDSTAR439>3.0.CO;2-E.

Stefanello, J., Bachi, L. M. A., Gavassoni, W. L., Hirata, L. M., \& Pontim, B. C. Á. (2012). Incidence of fungus in maize grains according to different times of fungicide foliar application. Pesquisa Agropecuária Tropical, 42(4), 476-481. http://dx.doi.org/10.1590/ S1983-40632012000400014.

Tester, R. F. (1997). Starch: the polysaccharide fractions. In: P.J. Frazier, P. Richmond, \& A.M. Donald. (Eds.), Starch: Structure and Functionality. London: Royal Society of Chemistry / AFI. pp. 163-171.

Vanderzant, C., \& Splittstoesser, D. F. (1992). Compendium of methods for the microbiological examination of foods. Washington: American Public Health Association.

Zhu, F. (2015). Composition, structure, physicochemical properties, and modifications of cassava starch. Carbohydrate Polymers, 122, 456-480. http://dx.doi.org/10.1016/j.carbpol.2014.10.063. PMid:25817690. 